\title{
PENGARUH JENIS GELLING AGENT TERHADAP AKTIVITAS ANTIBAKTERI EKSTRAK BUAH LIBO (FICUS VARIEGATA, BLUME)
}

\author{
Novika Anggraini Putri Heryan*,Viriyanata Wijaya, Mirhansyah Ardana \\ Laboratorium Penelitian dan Pengembangan Kefarmasian "Farmaka Tropis", \\ Fakultas Farmasi, Universitas Mulawarman, Samarinda, Indonesia \\ *Email: Novikanovika11@gmail.com
}

\begin{abstract}
Libo (Ficus variegata, Blume) is one of the plants that has been known to have secondary metabolites in the form of saponins and alkaloids which are quite dominant, where both compounds have antibacterial activity. The aim of this study was to determine the effect of the use of the gelling agent type on gel formulations in influencing the activity of Libo fruit extract (Ficus variegata, Blume) in Staphylococcus aureus and Propionibacterium acnes bacteria. The gel formula was made by varying the type of gelling agent to be used, namely HPMC and Carbopol. Antibacterial activity testing was carried out by the well diffusion method, then the observation of the diameter of the kill zone was carried out by looking at the clear zone formed around the well area. The results showed that the use of HPMC gelling agent did not affect the antibacterial activity and Carbopol could affect the antibacterial activity of libo fruit extract.
\end{abstract}

Keywords: Antibacterial Activity, Gel, Libo Fruit Extract

\begin{abstract}
ABSTRAK
Libo (Ficus variegata, Blume) merupakan salah satu tanaman yang telah diketahui memiliki metabolit sekunder berupa saponin dan alkaloid yang cukup dominan, dimana kedua senyawa tersebut memiliki aktivitas antibakteri. Tujuan dilakukannya penelitian ini adalah untuk mengetahui pengaruh penggunaan jenis gelling agent pada formulasi gel dalam mempengaruhi aktivitas ekstrak buah Libo (Ficus variegata, Blume) pada bakteri Staphylococcus aureus dan Propionibacterium acnes. Formula gel dibuat dengan memvariasikan jenis gelling agent yang akan digunakan yaitu HPMC dan Carbopol. Pengujian aktivitas antibakteri dilakukan dengan metode difusi sumuran, selanjutnya dilakukan pengamatan terhadap diameter zona bunuh dengan melihat adanya zona bening yang terbentuk disekitar area sumuran. Hasil penelitian menunjukkan bahwa adanya penggunaan jenis gelling agent HPMC tidak mempengaruhi aktivitas antibakteri dan Carbopol dapat mempengaruhi aktivitas antibakteri ekstrak buah libo.
\end{abstract}

Kata kunci: Aktivitas Antibakteri, Gel, Ekstrak Buah Libo

DOI: https://doi.org/10.25026/mpc.v8i1.319 


\section{PENDAHULUAN}

Acne Vulgaris atau jerawat merupakan suatu penyakit kulit obstruktif dan inflamatif kronik yang terjadi pada unit polisebasea yang sering terjadi pada masa remaja [23]. Gambaran klinis dari acne sangat beragam, dimulai dengan adanya komedo, papul, pustule, hingga nodus dan jaringan parut, sehingga dapat disebut dermatosis polimorfik dan memiliki peranan poligenetik [10]. Infeksi bakteri Staphylococcus aureus, Propionibacterium acnes dan $S$. epidermidis juga dapat menyebabkan munculnya suatu jerawat pada wajah [9]. Hasil survei di kawasan Asia Tenggara terdapat $40-80 \%$ kasus jerawat, sedangkan di Indonesia berdasarkan catatan kelompok studi dermatologi kosmetika Indonesia menunjukan terdapat $60 \%$ penderita jerawat pada tahun 2006 dan 80\% pada tahun 2007 [6].

Buah Libo (Ficus variegata, Blume) merupakan salah satu tanaman yang memiliki aktivitas antibakteri. Menurut Rijai, buah Libo (Ficus variegata, Blume) mengandung senyawa golongan metabolit sekunder diantaranya saponin dan alkaloid (sangat dominan) [16]. Kedua metabolit sekunder tersebut memiliki kemampuan sebagai antibakteri, dimana saponin akan berperan dalam penekanan pertumbuhan bakteri dan alkaloid akan menyebabkan kematian sel pada bakteri [5]. Berdasarkan penelitian Ramadhani (2012), didapatkan hasil konsentrasi terbaik pada ekstrak pekat etanol buah Libo ( $F$. variegata) sebesar 4,5\% dengan diameter zona bunuh pada bakteri Staphylococcus aureus sebesar 10,22 mm [14]. Menurut Ningsih (2016) dan Rusli, isolat fraksi etil asetat menunjukkan hasil posiif adanya aktivitas antibakteri pada bakteri Staphylococcus aureus dan Escherichia coli $[12,17]$.

Salah satu sediaan yang biasa ditemui untuk mengatasi jerawat adalah gel. Gel merupakan sediaan semipadat terdiri dari suspensi yang dibuat dari partikel anorganik kecil atau molekul organik yang besar yang bepenetrasi dalam cairan [4]. Selain itu alasan pembuatan sediaan farmasi dalam bentuk gel adalah nyaman saat digunakan dan memberikan sensasi dingin saat digunakan, mampu menghantarkan zat aktif dengan baik, dan menyebabkan jerawat cepat kering dan tidak menimbulkan bekas di kulit [22]

Berdasarkan latar belakang yang telah dipaparkan sebelumnya, maka permasalahan dalam penelitian ini dapat dirumuskan sebagai berikut: (a) Bagaimana aktivitas antibakteri pada ekstrak buah Libo (Ficus variegata, Blume) terhadap bakteri Propionibacterium acnes dan Staphylococcus aureus? (b) Apakah pemberian jenis gelling agent dapat mempengaruhi aktivitas antibakteri ekstrak buah Libo (Ficus variegata, Blume).

\section{METODE PENELITIAN}

\section{Alat dan Bahan}

Alat yang digunakan adalah Autoclave, batang pengaduk, blender, blue tip, cawan petri, gelas kimia $\left(\right.$ Pyrex $\left.^{\circledR}\right)$, gelas ukur (Pyrex ${ }^{\circledR}$ IWAKI) Hot Plate, inkubator, jarum Ose bulat, kaca arloji, Erlenmeyer $\left(\right.$ Pyrex $\left.^{\circledR}\right), \quad$ LAF (Laminar Air Flow), bunsen, magnetic stirrer, mikropipet, mikrometer skrup, object glass, pH meter, pipet ukur (IWAKI), rak tabung reaksi, Rotary Evaporator, sendok tanduk, spoid, tabung reaksi, timbangan analitik, pot gel, yellow tip dan viscometer Rheoys. Bahan yang digunakan adalah aquadest, biakan bakteri Staphylococcus aureus dan Propionibacterium acnes, buah Libo (Ficus variegata, Blume), Carbopol, HPMC, kapas, kasa, medium $\mathrm{Na}$ (Nutrient Agar), $\mathrm{NaCl}$ Fisiologis 0,9\%, TEA, Tween 20, dan spiritus. 


\section{Ekstraksi}

Sampel buah Libo yang telah dikumpulkan, dibersihkan dari pengotor, dipotong kecil-kecil lalu dikeringkan dengan menggunakan oven. Selanjutnya simplisia yang telah kering kemudian diserbukkan dan dilakukan proses ekstraksi maserasi dengan menggunakan pelarut etanol 96\% selama \pm 3 hari [20] Kegiatan ekstraksi dihentikan setelah seluruh metabolit sekunder yang ada dalam serbuk buah Libo telah terekstraksi kedalam pelarut etanol yang ditandai dengan warna larutan ekstrak menjadi bening dibandingkan dengan sebelumnya. Larutan ekstrak dipekatkan dengan rotary evaporator hingga diperoleh ekstrak pekat etanol buah libo [16]. Sisa pelarut diuapkan dengan cara diangin-anginkan di suhu ruang dan kemudian disimpan ke dalam desikator untuk menghindari tumbuhnya jamur dan mempertahankan ekstrak yang didapat dalam keadaan tetap kering [20]. Rendeman hasil ekstraksi dapat dinyatakan dalam rumus berikut:

Rendemen $(\% \mathrm{~b} / \mathrm{b})=\frac{\text { bobot ekstrak kental }}{\text { bobot serbuk simplisia }} \times 100 \%$

\section{Uji aktivitas antibakteri ekstrak buah libo}

Dilakukan sterilisasi alat-alat yang akan digunakan terlebih dahulu dengan menggunakan autoklaf dengan suhu $121^{\circ} \mathrm{C}$, kemudian disiapkan biakan murni bakteri Staphylococcus aureus dan Propionibacterium acnes pada media agar miring dan diinkubasi selama 1 x 24 jam, hasil inokulasi disuspensikan dengan larutan $\mathrm{NaCl} \quad 0,9 \%$ steril sehingga memenuhi standar McFarland 1,5 x $10^{8}$ CFU/ mL. Dimasukkan suspensi bakteri sebanyak $100 \mu \mathrm{L}$ dan $10 \mathrm{~mL}$ medium NA (Nutrient Agar) ke dalam cawan petri, homogenkan dan biarkan hingga memadat. Tiap cawan petri dibuat tiga sumuran, dan dimasukkan konsentrasi ekstrak yang akan diuji, kemudian diinkubasi pada suhu $37^{\circ} \mathrm{C}$ selama $18-24$ jam. Setelah itu diamati diameter zona hambat yang dihasilkan disekitar sumuran [1].

\section{Pembuatan sediaan gel ekstrak buah libo}

Komposisi formula sediaan gel ekstrak buah libo ditunjukkan melalui tabel 1 .

Tabel 1. Komposisi formula gel ekstrak buah libo

\begin{tabular}{ccc}
\hline Komposisi & F1 & F2 \\
\hline Ekstrak buah Libo & $4,5 \%$ & $4,5 \%$ \\
HPMC & $3,5 \%$ & - \\
Carbopol & - & $2 \%$ \\
TEA & - & $0,1 \mathrm{~mL}$ \\
Tween 20 & $10 \%$ & $10 \%$ \\
Aquadest ad & $100 \mathrm{~mL}$ & $100 \mathrm{~mL}$ \\
\hline
\end{tabular}

Pembuatan sediaan gel diawali dengan pelarutan terlebih dahulu tween 20 sebanyak 10 gram ke dalam $100 \mathrm{~mL}$ aquadest. Dilarutkan ekstrak dengan larutan tween sebanyak $80 \mathrm{~mL}$ dan diaduk hingga larut. Untuk formula 1, setelah ekstrak larut dapat ditambahkan HPMC sebanyak 3,5 gram dan dibiarkan hingga \pm 24 jam. Setelah mengembang dapat ditambahkan sisa larutan tween 20 dan diaduk dengan magnetic stirrer hingga homogen. Selajutnya pada formula 2, setelah ekstrak larut dapat ditambahkan carbopol sebanyak 2 gram dan dibiarkan hingga \pm 24 jam. Setelah mengembang dapat ditambahkan TEA 0,1 $\mathrm{mL}$ dan sisa larutan tween 20 dan diaduk dengan magnetic stirrer hingga homogen.

\section{Uji aktivitas antibakteri sediaan}

Dilakukan sterilisasi alat-alat yang akan digunakan terlebih dahulu dengan menggunakan autoklaf dengan suhu $121^{\circ} \mathrm{C}$, kemudian disiapkan biakan murni bakteri Staphylococcus aureus dan Propionibacterium acnes pada media 
agar miring dan diinkubasi selama 1 x 24 jam, hasil inokulasi disuspensikan dengan larutan $\mathrm{NaCl} \quad 0,9 \%$ steril sehingga memenuhi standar McFarland $1,5 \times 10^{8}$ CFU/ mL. Dimasukkan suspensi bakteri sebanyak $100 \mu L$ dan $10 \mathrm{~mL}$ medium NA (Nutrient Agar) ke dalam cawan petri, homogenkan dan biarkan hingga memadat. Tiap cawan petri dibuat empat sumuran berisi gel kontrol negatif dan gel uji dengan 3 replikasi tiap formulanya. Diinkubasi pada suhu $37^{\circ} \mathrm{C}$ selama $18-24$ jam. Setelah itu diamati diameter zona hambat yang dihasilkan disekitar sumuran [1].

\section{HASIL DAN PEMBAHASAN}

Sebanyak $5 \mathrm{~kg}$ buah libo segar yang telah dibersihkan dan dikeringkan kemudian dilakukan penyerbukan menghasilkan serbuk sekitar 688,1 gram. Serbuk tersebut kemudian dimaserasi dengan pelarut etanol $96 \%$ hingga warna larutan ekstrak menjadi bening, selanjutnya larutan ekstrak dipekatkan dengan rotary evaporator dan didapatkan ekstrak kental sekitar 429,2 gram. Rendemen ekstrak yang didapatkan dari perbandingan berat ekstrak dengan berat simplisia adalah 62,37\%.

Proses pembuatan sediaan gel ekstrak etanol buah libo mengikuti acuan yang telah ada, kemudian untuk penentuan konsentrasi ekstrak yang digunakan adalah sebesar 4,5\% dimana pada penelitian yang dilakukan Ramadhani (2012) pada konsentarasi tersebut didapatkan zona bunuh sekitar 10,22 $\mathrm{mm}$ terhadap bakteri Staphylococcus aureus yang merupakan salah satu bakteri penyebab jerawat. Selanjutnya sediaan dibuat dengan memvariasikan penggunaan jenis gelling agent yakni HPMC dan carbopol, dengan konsentrasi yang berbeda namun memiliki viskositas yang hampir sama. Adapun bahan tambahan lain diantaranya Tween 20, TEA dan aquadest.

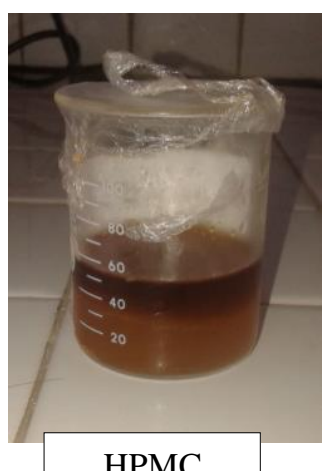

Gambar 1. Sediaan gel ekstrak buah Libo
Pengujian aktivitas antibakteri dimaksudkan untuk mengetahui besarnya pelepasan zat aktif dengan mengukur diameter zona hambat pertumbuhan bakteri. Metode yang digunakan pada penelitian ini adalah metode difusi agar yakni membuat sumuran pada media agar dengan diameter sumuran sebesar $6 \mathrm{~mm}$. Metode ini dipilih karena pengerjaannya relatif lebih mudah dan memungkinkan bahan uji sediaan gel dapat langsung bersentuhan dengan dinding media agar, sehingga akan lebih mudah dilihat secara visual daya hambat dengan pengukuran adanya zona radikal yaitu suatu daerah disekitar sumuran dimana bakteri dihambat oleh antibakteri [8].

Pengujian dilakukan dengan menggunakan konsentrasi terbaik dari acuan penelitian sebelumnya yaitu $4,5 \%$, dimana pada penelitian sebelumnya pada konsentarsi tersebut didapatkan zona bunuh sekitar 10,22 mm pada ekstrak pekat etanol buah libo [14]. Kemudian pengujian antibakteri juga dilakukan pada masing-masing formula sediaan dan basis gel tanpa penambahan ekstrak.

Diameter daerah hambatan (zona hambatan) di sekitar sumuran diukur dengan mikrometer sekrup dengan cara mengukur secara horizontal dan vertikal [13] kemudian dibagi dua sehingga dihasilkan diameter zona hambat dari keseluruhan diameter yang terbentuk. 


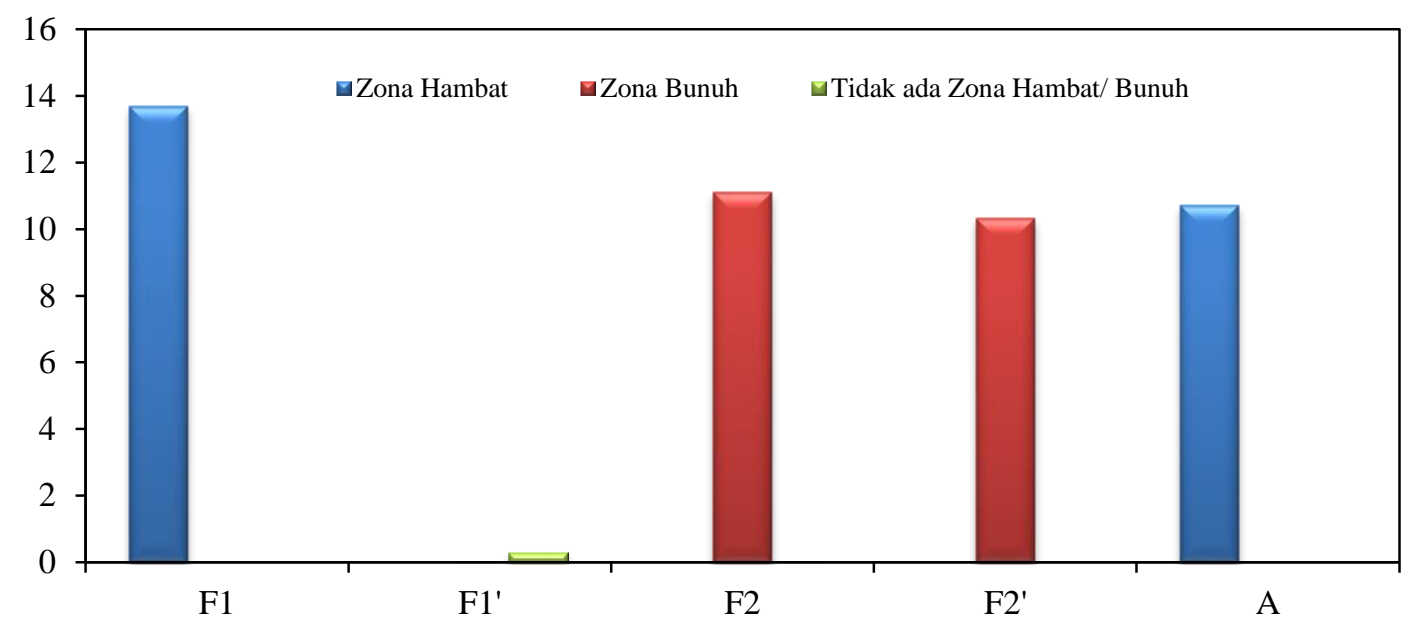

Gambar 2. Zona yang terbentuk pada Bakteri Staphylococcus aureus

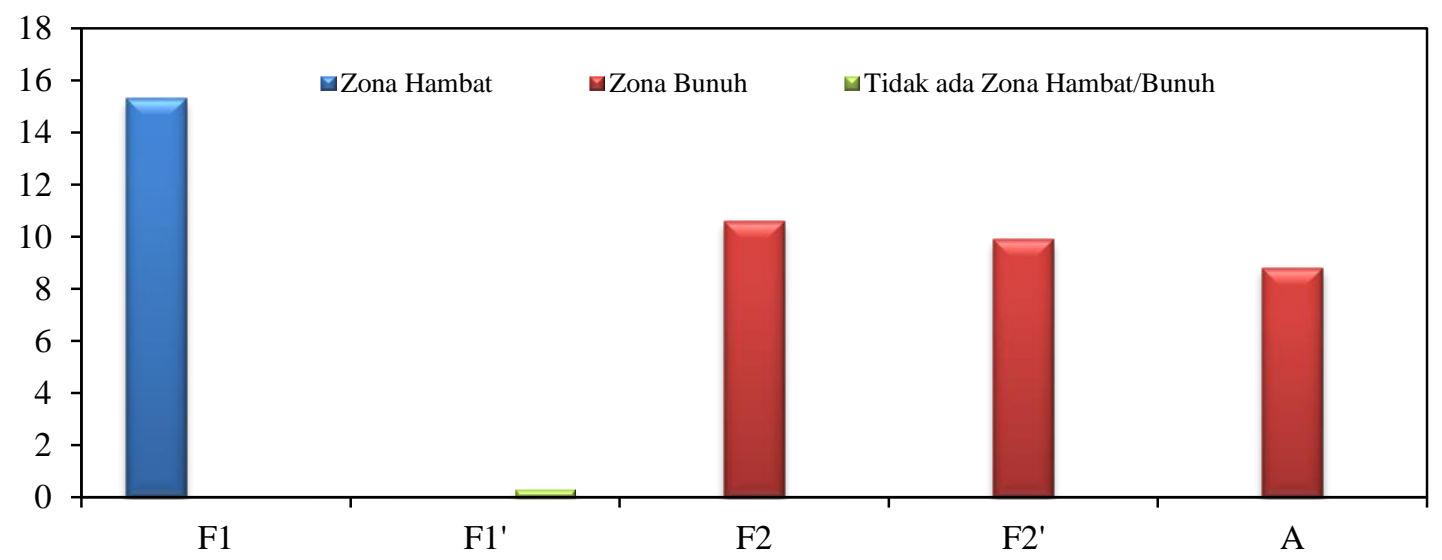

Gambar 3. Zona yang terbentuk pada Bakteri Propionibacterium acnes

Keterangan : F1 = Formula dengan basis HPMC dengan ekstrak

$\mathrm{F} 1^{\prime}$ = Formula dengan basis HPMC tanpa ekstrak

$\mathrm{F} 2$ = Formula dengan basis Carbopol dengan ekstrak

F2' $=$ Formula dengan basis Carbopol tanpa ekstrak

A $\quad=$ Ekstrak Etanol Buah Libo

Berdasarkan hasil pengujian yang telah dilakukan terdapat adanya zona hambat maupun zona bunuh pada ekstrak yang diuji, hal ini dikarenakan adanya kandungan alkaloid dan saponin pada ekstrak yang berperan sebagai antibakteri. Senyawa alkaloid akan secara umum mengganggu komponen penyusun peptidoglikan pada sel bakteri, sehingga lapisan dinding sel tidak terbentuk secara utuh dan menyebabkan kematian pada sel tersebut. Selain itu adanya gugus basa nitrogen pada alkaloid akan bereaksi dengan asam amino penyusun dinding sel dan DNA bakteri sehingga akan terjadi perubahan struktur dan susunan asam amino yang akan menyebabkan terjadinya lisis sel bakteri [5]. Sedangkan pada senyawa saponin akan berikatan dengan lipopolisakarida pada dinding sel bakteri yang akan mengakibatkan meningkatnya permeabilitas dinding sel dan menurunkan tegangan permukaan dinding sel sehingga ketika terjadi 
interaksi dinding sel tersebut akan pecah atau mengalami lisis dan membuat zat antibakteri akan masuk ke dalam sel dengan mudah dan akan mengganggu metabolisme sehingga hasil akhirnya akan terjadi kematian pada bakteri [18].

Hasil penelitian menunjukkan perbedaan zona yang terbentuk pada masing-masing formula. Pada formula 1 dengan HPMC sebagai gelling agentnya memperlihatkan adanya zona hambat yang terbentuk yakni $13,7 \mathrm{~mm}$ pada bakteri Staphylococcus aureus dan 15,3 $\mathrm{mm}$ pada bakteri Propionibacterium acnes. Jika dibandingkan dengan formula 1 tanpa penambahan ekstrak yang tidak memiliki zona hambat maupun zona bunuh, maka hasil yang didapatkan sudah dapat dikatakan bahwa HPMC sebagai jenis gelling agentnya tidak mempengaruhi aktivitas antibakteri. Namun untuk homogenitas sediaan gel ekstrak buah libo menunjukkan tingkat homogenitas yang rendah, dimana terlihat pemisahan menjadi 2 fase pada sediaan. Sedangkan pada formula 2 dengan carbopol sebagai gelling agentnya, baik pada formula tanpa penambahan ekstrak dan penambahan ekstrak sama-sama menunjukkan adanya zona bunuh yang terbentuk. Zona bunuh yang terbentuk pada formula 2 dengan penambahan ekstrak menunjukkan peningkatan diameter zona bunuhnya jika dibandingkan dengan formula tanpa penambahan ekstrak. Setelah dilakukan pengecekan $\mathrm{pH}$ sediaan, pada formula tanpa penambahan ekstrak menunjukkan $\mathrm{pH}$ 2,5 dan 4,5 pada formula dengan penambahan ekstrak. Hal inilah yang menyebabkan terbentuknya zona bunuh pada formula tanpa ekstrak, dimana menurut Cepeda (2015), tingkat keasaman $(\mathrm{pH})$ yang rendah memiliki dampak sinergis terhadap daya antibakteri. Asam dapat menurunkan $\mathrm{pH}$ sitoplasma sel bakteri dan berdampak pada terganggunya kerja enzim-enzim di dalam sel dan aktivitas transportasi melalui membran termasuk transport nutrien ke dalam sel [15], serta dapat menyebabkan kerusakan membran luar sel dan menyebabkan senyawa-senyawa antibakteri yang bersifat hidrofobik lebih mudah masuk dalam sel [2]. Perubahanperubahan tersebut diduga akan menyebabkan sel-sel bakteri lebih rentan terhadap senyawa-senyawa antibakteri yang masuk ke dalam sel sehingga $\mathrm{pH}$ yang rendah akan meningkatkan daya antibakterinya [3].

\section{KESIMPULAN}

Berdasarkan penelitian yang telah dilakukan maka dapat disimpulkan bahwa penggunaan jenis gelling agent seperti HPMC tidak mempengaruhi aktivitas antibakteri dan Carbopol dapat mempengaruhi aktivitas antibakteri ekstrak buah libo.

\section{SARAN}

Perlu dilakukan penelitian lebih lanjut untuk mengoptimalkan sediaan gel ekstrak etanol buah libo agar dapat memenuhi parameter uji kualitasnya.

\section{DAFTAR PUSTAKA}

[1] Afianti, Hanum Pramuji., Murukmihadi, Mimiek. 2015. Pengaruh Variasi Gelling Agent HPMC Terhadap Aktivitas Antibakteri Sediaan Gel Ekstrak Etanolik Daun Kemangi (Ocimum Basilicum L. Forma Citrtum Back.). Fakultas Farmasi Universitas Gadjah Mada, Yogyakarta. Majalah Farmaseutik Vol. 11 No. 2

[2] Alakomi, H.L., Skytta, E., Saarela, M. dan Mattila-Sandholm, T. 2000. Lactic acid permeabilizes gramnegative bacteria by disrupting the outer membran. Applied environmental microbiology hal.66

[3] Cepeda, Gino Nemesio; Lisangan, Meike Meilan; Silamba, Isak. 2015. Aktivitas Antibakteri Ekstrak Kulit Kayu Akway (Drimys Piperita Hook F.) Terhadap Bakteri Patogen. Fakultas Pertanian dan Teknologi 
Pertanian, Universitas Negeri Papua. Agritech, Vol. 35, No. 2

[4] Departemen Kesehatan Republik Indonesia. 2014. Farmakope Indonesia Edisi $V$. Departemen Kesehatan RI. Jakarta

[5] Farida, R., Dewa, M., Titis, N., Endrawati. 6. 2010. Manfaat Sirih Merah (Piper Crocatum) Sebagai Agen Anti Bakterial Terhadap Bakteri Gram Positif Dan Gram Negatif. Jurnal Kedokteran Dan Kesehatan Indonesia.

[6] Gurriannisa, R. 2010. Gambaran Tingkat pengetahuan dan Sikap Siswa SMA Negeri 5 Medan Terhadap Jerawat Tahun 2010. Karya Tulis Ilmiah. Fakultas Kedokteran Universitas Sumatera UtaraMedan, 1-11.

[7] Hardiningtyas, S.D. 2009. Aktivitas Antibakteri Ekstrak Karang Lunak Sarcophyton Sp. Yang Difragmentasi dan Tidak Difragmentasi Di Perairan Pulau Pramuka, Kepulauan Seribu. Institut Pertanian Bogor: Bogor.

[8] Jawetz., E., Melnick, J.L., \& Adelbeg, E.A. 2005. Mikrobiologi Kedokteran. Hal. 315-326, 352-360. Penerbit Salemba Medika, Jakarta.

[9] Khan.A. J, Kumar.N. 2011.Evaluation of Antibacterial Properties of Extracts of Piper betel Leaf, Journal of Pharmaceutical and Biomedical Sciences, ISSN No-22307885, 11(01)

[10] Kurokawa I, Danby FW, Ju Q Wang $X$, Xiang LF, Xia L, Chen WC, Nagy I, et al. 2009. New Developments In Our Understandig of Acne Pathogenesis and Treatment. Experimental Dematology, 18:821823

[11] Martin, A., Swarbick, J., Cammarata, A. 1990. Dasar-Dasar Farmasi Fisik Dalam Ilmu Farmasi, Jilid 1. Penerbit Univeritas Indonesia. Jakarta. 25.
[12]Ningsih, B. A., Rahmadani, A., Fadraersada, J., \& Rusli, R. (2016). Aktivitas Antibakteri Dan Antioksidan Isolat Fraksi Etil Asetat Buah Libo (Ficus variegata Blume.). Proceeding of Mulawarman Pharmaceuticals Conferences, 3(2), 114-120. https://doi.org/10.25026/mpc.v3i2.95

[13] Nurvianty, Astrid; Wullur, A. C.; dan Wewengkang, Defny S.. 2018. Formulasi Sediaan Gel Ekstrak Etanol Daun Awar-Awar (Ficus Septica Burm) Dengan Variasi Basis Hpmc dan Aktivitasnya Terhadap Staphylococcus Epidermidis. Sulawesi Utara: Program Studi Farmasi Fmipa Unsrat Manado. ISSN 2302-2493 Vol.7 No.1

[14] Ramadhani, A. 2012. Uji Antibakteri Ekstrak Buah Libo (F. Variegata). Skripsi. Fakultas Farmasi Universitas Mulawarman, Samarinda.

[15]Ray, B. 2001. Fundamental food microbiology. ${ }^{2 n d}$ edn, CRCPress, New York.

[16]Rijai, Laode. 2013. Potensi Tumbuhan Libo (Ficus Variegata Blume) Sebagai Sumber Bahan Farmasi Potensial. J. Trop. Pharm. Chem. Vol. 2 No.3

[17]R Rusli, BA Ningsih, A Rahmadani, L Febrina, V Maulidya, J Fadraersada. Isolation and Antioxidant and Antibacterial Activity of Flavonoid from Ficus variegate Blume. Indonesian Journal of Chemistry (Accepted)

[18] Sari, Intan. P; Wibow, M. Agus; Arreneuz, Savante. 2015. Aktivitas Antibakteri Ekstrak Teripang Butoh Keling (Holothuria Leucospilota) Dari Pulau Lemukutan Terhadap Bakteri Propionibacterium Acnes dan Staphylococcus Epidermidis. Jkk, ISSN 2303-1077 Volume 4(4), Halaman 21-28

[19] Suardi, M., Armenia, dan Maryawati, A. 2008. Formulasi dan Uji Klinik Gel Antijerawat Benzoil Peroksida- 
HPMC. Sumatra Barat: Fakultas Farmasi Universitas Andalas.

[20]Rusli, R., Ardana, M., Tambunan, S.M., 2018. Antiseptic Formulation of Libo Extract (Ficus varieagata Blume). International Journal of ChemTech Research.11 (05). 281284.

DOI: http://dx.doi.org/10.20902/IJCTR.20 18.110530

[21] Voight, R. 1994. Buku Pelajaran Tekhnologi Farmasi. Gajah Mada University Press. Yogyakarta. 341.
[22] Yulia, A., Esti, H, Tutiek P. 2012. Karakteristik Sediaan dan Pelepasan Natrium Diklofenak dalam Sisten Niosom dengan Basis Gel Carbomer 940. PharmaScientia, 1 (1):2.

[23]Zaenglein Al; Graber EM; Thiboutot DM; Strauss JS. 2008. Acne Vulgaris And Acneiform Eruption. In: Fitzpatrick TB, Eisen AZ, Wolff K, Freedberg IM, Austen K, eds. Dermatology in general medicine. $7^{\text {th }}$ ed. New York: McGraw-Hill, 690703 